\title{
COVID-19 IMPACT ON MOROCCAN SMALL AND MEDIUM-SIZED ENTERPRISES: CAN LEAN PRACTICES BE AN EFFECTIVE SOLUTION FOR GETTING OUT OF CRISIS?
}

\author{
Aicha FARISSI, Laila DRIOUACH, Khalid ZARBANE, \\ Mohamed EL OUMAMI, Zitouni BEIDOURI \\ High School of Technology Casablanca, Hassan II University of Casablanca
}

\begin{abstract}
:
The COVID-19 crisis hit the economy hard, it is a global situation of declining activity due to a highly contagious disease which has pushed the world to the brink of a deeper recession than ever. Small and medium-sized enterprises constitute $92 \%$ of the Moroccan economic fabric, they are among the organizations most seriously affected by the current pandemic. This paper examines the problems that exist before and during this crisis, in order to raise major challenges and choose the ideal approach that will strengthen the competitiveness of these companies. the analysis is based on secondary data and the literature to demonstrate the different constraints of these companies and to show the importance of lean manufacturing as the guarantor of industrial performance. the main question is how the alignment of Lean principals goes well with the desired improvement and with the constraints posed by this crisis, the primary objective of Lean is to provide the means to succeed and accelerate competitiveness. Finally, these circumstances can be a real opportunity to assist Small and Medium Moroccan companies to integrate the methods they need, and "Lean approach" is one of the best performance solutions to adopt in a post COVID-19.
\end{abstract}

Key words: COVID-19, Impact, Lean, Morocco, Small and medium enterprises (SMEs)

\section{INTRODUCTION}

The outbreak of COVID-19 (the disease caused by Severe Acute Respiratory Syndrome Coronavirus 2 (SARS-COV-2) has had detrimental effects on global healthcare systems, with the ripple effect on every aspect of human life. COVID-19 as well has impacted various economic sectors: the primary sectors which include industries involved in the extraction of raw materials [47, 55, 62]. Secondary sectors involved in the production of finished products and tertiary sectors including all service provision industries [7, 18, 55]. In fact, import issues and staffing deficiencies stood out as the key concerns for businesses due to disruption to supply chains and self-isolation policies. Indeed, for many roles within a manufacturing company, 'working from home' is not a viable option [55]. Moreover, Millions of jobs will be lost, with global assessment from the International Labor Organization (ILO), five to 25 million jobs will be eradicated, and the world will lose $\$ 860$ billion to $\$ 3.4$ trillion in labor income. Health and unemployment insurance and social protection are necessary, to also support business (large, medium, small scales) to prevent job losses [21].

Small and medium enterprises (SMEs) are possibly the hardest hit in all the countries need special economic revitalization package [63]. Small and medium enterprises are likely to be severely affected, as they tend to be more concentrated in sectors that have been directly affected by COVID-19 response measures and are typically more credit constrained than larger businesses [14, 46]. Importantly, small businesses make up the majority of companies, and are responsible for a substantial fraction of employment [39]. Lean is a whole integrating many principles, tools and techniques whose aim is reducing all sources of value chains inefficiencies and meanwhile bridging the gaps between actual performance and customer requirements [22].

In this paper, the first step is to see what is the impact of this crisis on the entire Moroccan economy? Then, analyze the situation of these companies during this crisis and compare it with the initial state (during crisis). The last step is to show how Lean will enable companies to remedy both the problems directly linked to the COVID-19 crisis and even those linked to the previous situation of these organizations.

\section{LITERATURE REVIEW}

Lean manufacturing or lean production is a systematic method for waste reduction within manufacturing production without losing productivity. Lean was initially developed by Toyota to eliminate waste and inefficiency in 
its manufacturing operations [71]. This development became so successful that it is being used in manufacturing around the world. Numerous studies have dealt with the positive impacts of Lean on the industrial performance of companies $[1,5,23,53,59,61]$. There are many tangible benefits associated with Lean Manufacturing. They are classified in three categories: operational, administrative and strategic [45].

Benefits in figure 1 have been observed in both Large Enterprises (LGs) and Small and Medium Enterprises (SMEs) $[5,19,23,45,61]$ as well as in many sectors of activity and even in the service sector [20]. The benefits generated by Lean are not limited to the improvement of operational, strategic and administrative performance as the success of a Lean system depends largely on the human dimension [22]. Indeed, the Lean implementation leads to an improvement in employee motivation, in employee productivity, and in the skills and versatility of staff $[5,67]$. Lean manufacturing also makes it possible to offer better working conditions, reduce stress, stimulate team spirit, engage the company in continuous improvement processes, develop employee relations with management, and encourage teamwork based on effective productivity and rigor (Fig. 1) [23].

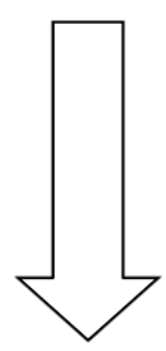

$$
\begin{gathered}
\text { Reduction in: } \\
\text { Defects } \\
\text { Lead time } \\
\text { Inventory } \\
\text { Production cost } \\
\text { Floor space occupied } \\
\text { Waste } \\
\text { Changeover times } \\
\text { Administrative function } \\
\text { costs }
\end{gathered}
$$

$$
\begin{gathered}
\text { Improvement in: } \\
\text { Productivity } \\
\text { Customer satisfaction } \\
\text { Capacity } \\
\text { Quality } \\
\text { Profit } \\
\text { Service rate } \\
\text { Turnover } \\
\text { Sales volume } \\
\text { Responsiveness } \\
\text { Knowledge management } \\
\text { Staff motivation } \\
\text { Staff skills and versatility } \\
\text { Teams spirits }
\end{gathered}
$$

Fig. 1 Lean benefits

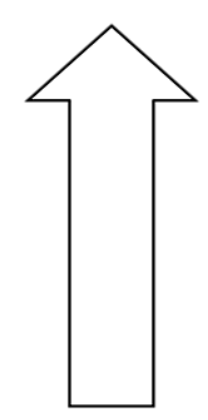

The current economic situation of COVID and its repercussion on performance of small companies, is ever more prompting business managers to benefit from these Lean contributions especially on employees if it is considered that the human factor is the most sensitive and most critical in this economic crisis.

\section{METHODOLOGY}

The methodology of this paper based on a three-step approach (Fig. 2). The first step consisted in answering the question on the seriousness of this pandemic on Moroccan companies. The second stage consisted in collecting data from the literature on the initial situation of these companies in order to be able to analyze the constraints, which slow down the improvement of the level of performance. Finally, the last step consists in discussing Lean as an approach to increase efficiency, as well as social security techniques for the benefit of employees and society.

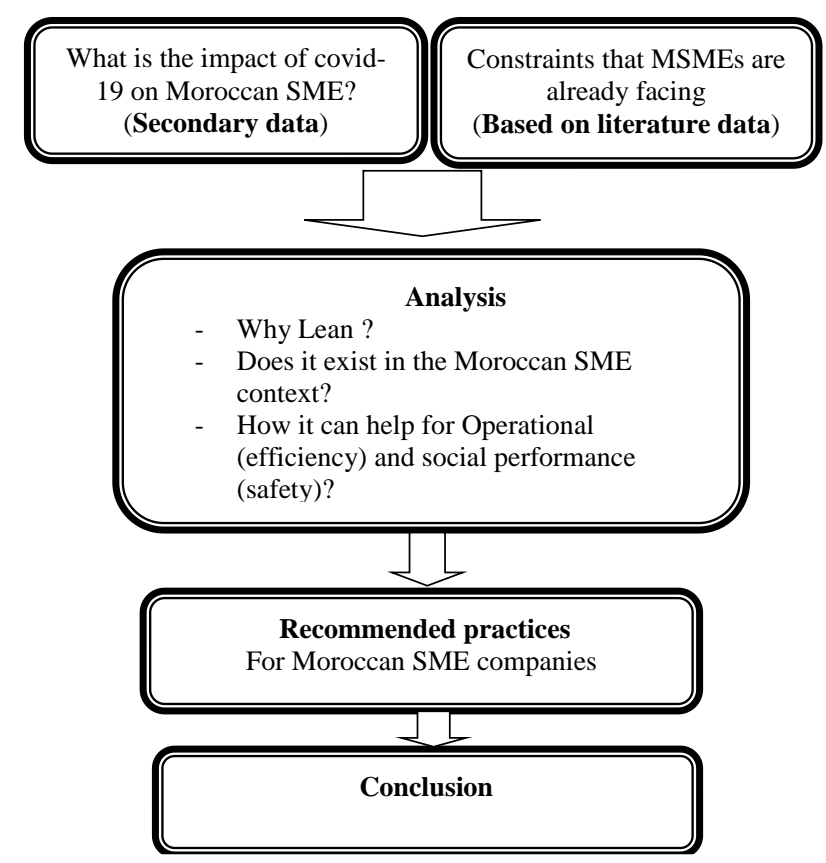

Fig. 2 Research methodology

Obviously, Moroccan economy would be adversely affected this year, because of this negative impact of the disease. For instance, based on information collected up to April 20, after a confinement period of one month, economic growth would not have exceeded $+0.7 \%$ in the first quarter of 2020 , instead of $+1.9 \%$, without the effect of COVID-19 [43]. According to the World Bank report, Because of this difficult period plus the drought, the country is expected to go into recession this year, sort of a crisis that hasn't appeared in twenty years, especially if the pandemic extend yet [69]. In addition, the baseline of the World Bank implies a decrease of 1.5\% of GDP in 2020. Besides, The International Monetary Fund forecasts a $3.7 \%$ drop in GDP for 2020 and a $4.8 \%$ recovery in 2021 [2]. Coronavirus brings industrial companies in morocco to a standstill (see Figure 3). As serious consequences: disruption of the raw material supply chain with a decrease in foreign demand [69]. About $27 \%$ of companies have temporarily or permanently reduced their workforce, nearly 726,000 jobs ( $20 \%$ of the workforce of organized companies), excluding the financial and agricultural sectors. And $57 \%$ of the dismissed employees worked in small and medium entreprises (SMEs) [36].

According to the published results of the qualitative survey carried out by the High Commission for Planning, out of a sample of 4,000 organized Moroccan companies operating in the manufacturing industry sectors, here is in the figure below, the impact of the COVID-19 pandemic on different industrial sectors. 
Moroccan industrial companies, which have definitively stopped their activity

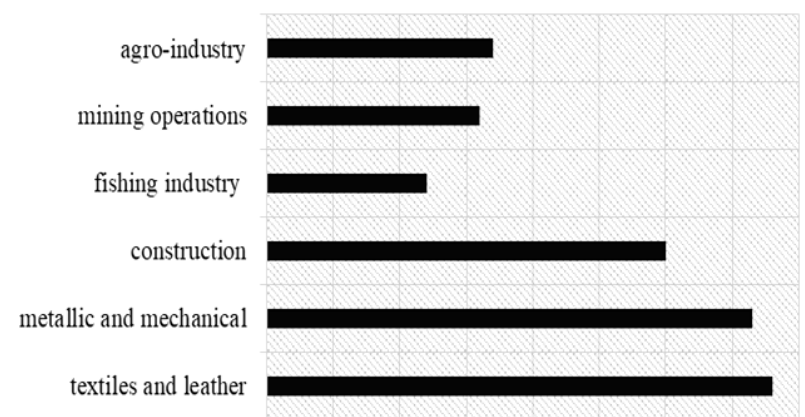

$\begin{array}{llllllllll}0 \% & 10 \% & 20 \% & 30 \% & 40 \% & 50 \% & 60 \% & 70 \% & 80 \%\end{array}$

Fig. 3 Impact of COVID-19, results of a qualitative study on a sample of 4000 Moroccan companies (based on High Commission for Planning)

Moroccan Small and medium companies during the critical period of COVID-19

A study published by the High Commission for Planning [36], about the immediate impact of the COVID-19 crisis on Moroccan companies, showed that nearly 142,000 units have permanently or temporarily ceased their activities (i.e. $57 \%$ of the total number of companies). Very small companies are the most affected, representing $72 \%$ of companies in difficulty, while $26 \%$ are SMEs and only $2 \%$ of large companies (see Fig. 4).

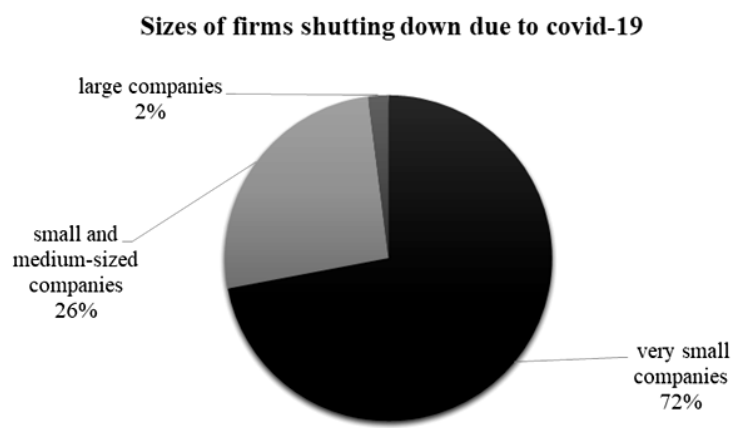

Fig. 4 Sizes of Moroccan firms shutting down due to COVID-19

It should be noted that an economic crisis does not affect all enterprises in the same way [31]. As already indicated by [66], surviving in times of crisis is a major constraint for small and medium entreprises, due to the lack of interest and protection acquired by them compared to large enterprises. In fact, SMEs are the most affected by the COVID-19 crisis because of their poor performance before the outbreak of the crisis, which influences their level performance level after the COVID-19 outbreak.

Situation of Moroccan small and medium entreprises: before COVID-19 outbreak

The number of bankruptcies of Moroccan SMEs is very high and extremely disturbing (more than 8,000 enterprises went bankrupt in 2017 and 8,439 in 2019, Very small companies are always the first to suffer from failures $[41,42]$. Nevertheless, scientific researchers still do not attach importance to this subject in order to analyze the main causes of this bad situation [3]. In fact, this is a very worrying situation because the consequences are very serious, both on the economic and social axis.
Small and medium-sized companies are recognized by qualitative characteristics that can also be considered as constraints, which hinder their development, such as their small size, which does not help them cover their fixed costs [68]. Including that, they are marked by the omnipresence of the manager at all levels of the company's management [25] the centralization of decision-making [64]. Furthermore, these constraints generally associated with small enterprises can affect the level of productive capacity, and to remedy this, it will be necessary to work on intangible resources to enhance their competitiveness companies are perceived as opaque [49] by their inability to provide reliable information to the various stakeholders. As for difficulties linked to resources, there is a remarkable lack at the financial level of Moroccan Small and medium-sized companies (SMEs) [34]. For example, on the basis of a survey of 174 small and medium-sized enterprises in Morocco, monitoring and managing cash flow is the main concern of this type of companies, rather profitability, since any need would weigh heavily on financial costs (cash flow) $[4,13,15]$.

Human resources, through their skills and experience, constitute the backbone of the processes of these Moroccan entreprises. But unfortunately, the managers of these firms do not make an effort to improve this cognitive capital through continuous employee training, and they do not invest in this component [51].

The High Commission for Planning (HCP) survey results in 2019 show that only $18 \%$ of SMEs benefit from coaching as part of company management. Based on same study, the training rate for skills development training is $6 \%$ for very small enterprises and $30.0 \%$ for SMEs, while it is $74.9 \%$ for large enterprises. According to the same study, lack of interest (66.7\%) has constituted the main reason for reluctance to train [35].

While learning ability is a competitive advantage in turbulent times [12] and organizational learning is a pillar that ensures the survival of the organization [33,65]. Despite all that, Moroccan small and medium entreprises (SMEs) managers do not attach any importance to organizational learning for developing competencies. Thus, as indicated by [24] in times of instability, small and medium entreprises in Morocco (SMEs) are strongly encouraged to review their methods and restore their strategy.

\section{RESULTS}

Based on the above, we present in (Fig. 5) below an analysis summary of Moroccan small and medium companies limitations and issues (before and during COVID-19):

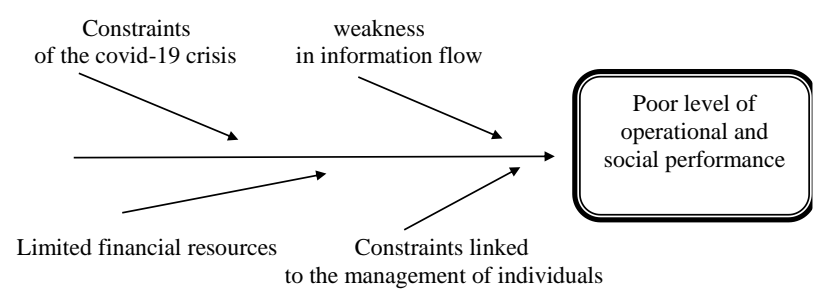

Fig. 5 Main constraints related to Moroccan small and medium companies (SMEs) 
Since the main aspect of the Lean strategy is the search for continuous improvement of the entire system, products and processes [56]. Thus, we propose the Lean approach as an effective solution to these problems. Both those linked to the size characteristics, to the nature of the industry, also those imposed currently by the outbreak of the COVID-19 crisis. Mainly which are linked to the management of the working environment, In order to minimize the movements, and maintain social distance. The table below (see Table 1) summarizes the most important challenges faced by small businesses. Here are the proposals of the most appropriate of Lean practices to overcome these difficulties.

Table 1

Based on the literature, here are some recommended practices for overcoming the challenges

Components of challenge axes
Social/operational performance
Recommended practice
How was it mentioned in the Moroccan context?

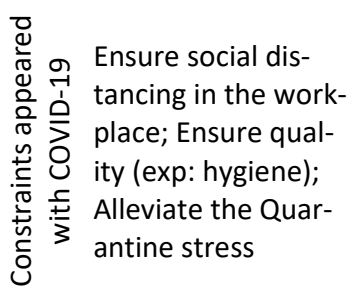

Lean is an approach that has shown its ability to ensure safety at the level of the working environment, an interesting commitment of the collaborators, with a better quality as well as the high profitability of the personnel $[28,50,54,71]$
Lack of skills and expertise; low level of organizational learning

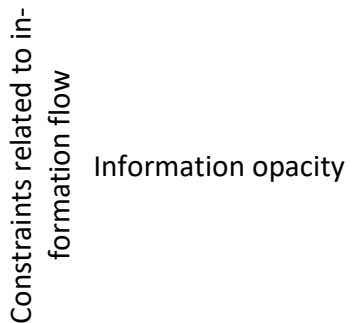

Limited resources; High cost price; Lack of infrastructure; disruption of raw material (due to COVID-19)
The lean approach makes it possible to provide information, to measure the various differences, in order to improve the processes, which can positively affect the state and the situation as well as the safety of the workplace $[27,52]$.

Lean practices affects positively operational performance, and JIT adoption leads to increased inventory turnover $[6,40]$ numerous studies have addressed the relationship between Lean and financial performance [16, 26]. Furthermore, companies with inventory levels below the industry average tend to have higher stock returns $[16,38]$
$5 S$ is an approach that involves sectioning, organizing, cleaning, standardizing and maintaining a clean and productive work environment [32]. In addition, $5 S$ has proven to be an effective communication method, mainly at the operational workshop level $[10,57]$. It ensures that production workers are actively involved in improvement and restructuring efforts, while feeling sufficiently safe in their current workplace $[44,72]$.

\section{Human management}

For the implementation of the lean approach in a Moroccan context,

Since workforce development plays an important role in the performance of organizations, it is necessary to achieve "appropriate use of the human element" $[11,60]$. According to [58] the use of highly developed and trusted personnel is the main differentiator of the Lean system.

Visual management is described as "visual cues and guidelines to more clearly assist and guide employees to appropriate actions and locations" [29]. The key principle of visual communication is the sharing of information, which leads to share power, control and responsibility, thereby improving support and motivation [30].

Supplier relationship management practices (SCM) and the implimentaion of JIT practices to manage inventory for reducing costs.

Based on the study [8] of "Amine Belhadi 2016", Through case studies of five Moroccan SMEs, which have all successfully implemented Lean, $5 S$ is very important, it is part of the best starting practices, for the organization of the workplace.

Larteb, Haddout, and Benhadou, 2006 [48], have shown that the critical and main success factors is the human factors, either at the level of the management, or of the employees. Which means to get out of the critical moments, the development and improvement programs must be focused on the human being (awareness, learning, communication)

Chafi, 2020 [17] showed the effectiveness of the VSM implementation for the Moroccan company, and which will allow it to eliminate the various sources of waste.

Velda, 2019 [70] has demonstrated that SCM practices have an important impact on financial performance in Morocco, mainly, supplier relationship management; communication; Flow Coordination and Information Sharing, which are the most significant elements for improving financial performance. 


\section{CONCLUSION}

The study revealed the impacts of COVID-19 on small and medium Moroccan entreprises. Then a literature search was conducted to provide clear answers to the question raised at the beginning: how Lean Manufacturing can remedy the effects of COVID-19 on these Moroccan companies? The goal is to demonstrate how lean practices are helping employees operate safely during this critical period of the pandemic. In the end, there is the recommendation of some selected lean practices to improve performance. Here is a summary of the how these Lean tools can contribute to the prevention measures against the pandemic:

- The 5S Lean tool is the most important tool to be associated with COVID-19. 5S is the basis of the Lean approach, which allows social distancing and helps to prevent the spread of this vicious disease. Indeed, the use of $5 \mathrm{~S}$ ensures organization, cleaning, standardization; which allows employees to be more attentive to the respect of COVID-19 protection instructions, to limit employee stress and to ensure maintaining of hygiene.

- Visual management allows the sharing of information and communication via visual tools which minimizes contact between employees and thus contributes to social distancing measures

Covid crisis allowed us to start thinking about how to transform our societies and embrace Lean culture and Lean's way of managing processes, whatever the type of process to do. For example, nations that have reached Lean culture, including China, Japan, South Korea, and some other countries, are likely to cope with the consequences of COVID-19 more easily and with less damage. For example, reducing the movement of people minimizes adverse events and sequel of COVID-19 and reduces causes leading to transmission of the infection with the person to person.

Finally, it is recommended that this study be revised by a practical case study in small manufacturing companies to demonstrate the effectiveness of our solution and to approve that the proposed Lean practices allow at the same time for efficiency and social distancing measures in COVID-19 time.

\section{REFERENCES}

[1] F.A. Abdulmalek, J. Rajgopal. "Analyzing the benefits of lean manufacturing and value stream mapping via simulation: A process sector case study." International Journal of Production Economics, vol. 107, no. 1, pp. 223-236, May 2007. DOI:10.1016/j.ijpe.2006.09.009.

[2] A. Ait Ali et al. "La Stratégie Du Maroc Face Au COVID19." Policy Center for the New South, p. 37, Apr. 2020.
[3] Asli, A. Zohri, N. Manzani. "Factors That Explain Entrepreneurial Failure Of Moroccan SMES, An Exploratory Study." Presented at the $8^{\text {th }}$ International OFEL Conference on Governance, Management and Entrepreneurship, Dubrovnik, Croatia, Apr. 2020, p. 2016.

[4] S. Bahyaoui. "Systèmes De Mesure De La Performance (SMP) Dans Les PME Marocaines: Les Résultats D'une Recherche Exploratoire." European Scientific Journal, ESJ, vol. 13, no. 10, p. 149, Apr. 2017. DOI:10.19044/esj.2017.v13n10p149.

[5] G. Baglin, M. Capraro. "L'Entreprise Lean Production ou la PME compétitive par l'action collective." Presses Universitaires de Lyon, 1999.

[6] R. Balakrishnan, T.J. Linsmeier, M. Venkatachalam. “Financial Benefits from JIT Adoption: Effects of Customer Concentration and Cost Structure." The Accounting Review, vol. 71, no. 2, 1996, pp. 183-205.

[7] R. Baldwin, E. Tomiura. "Thinking ahead about the trade impact of COVID-19", in Economics in the Time of COVID-19, vol. 59, London: Centre for Economic Policy Research, 2020. pp. 59-71.

[8] A. Belhadi, F.E. Touriki, S. El Fezazi. "Road Map for the Implementation of Lean production tools in SMEs", in Proceedings of International Conference on Industrial Engineering and Operations Management Kuala Lumpur, Malaysia, March 8-10, 2016.

[9] J. Bessant, D. Francis. "Developing strategic continuous improvement capability". International Journal of Operations and Production Management, 1999. vol. 19, no 11, pp. 1106-1119.

[10] N. Bilalis, G. Scroubelos, A. Antoniadis, D. Emiris and D. Koulouriotis. "Visual factory: Basic principles and the 'zoning' approach. " International Journal of Production Research, vol. 40, no. 15, 2002, pp. 3575-3588, DOI:10.1080/00207540210140031.

[11] T. Bonavia, J.A. M. Garcia. "Integrating human resource management into lean production and their impact on organizational performance". International Journal of Manpower, vol. 32, no. 8, 2011, pp. 923-938, DOI:10.1108/01437721111181679.

[12] N. Bontis, M.M. Crossan, J. Hulland. "Managing An Organizational Learning System By Aligning Stocks and Flows. " Journal of Management Studies, vol. 39, no. 4, 2002, pp. 437-469, DOI:10.1111/1467-6486.t01-100299.

[13] N. Boso, V.M. Story, J.W. Cadogan., J. Annan, S. KadićMaglajlić and M. Micevski. "Enhancing the sales benefits of radical product innovativeness in internationalizing small and medium-sized enterprises. " Journal of Business Research, vol. 69, no. 11, 2016, pp. 5040-5045, DOI:10.1016/j.jbusres.2016.04.077.

[14] S. Cao, D. Leung. "Credit constraints and productivity of SMEs: Evidence from Canada". Economic Modelling, vol. 88, 2020, pp. 163-180, DOI:10.1016/j.econ$\bmod$ 2019.09.018. 
[15] S.T. Cavusgil, G. Knight. "The born global firm: An entrepreneurial and capabilities perspective on early and rapid internationalization". Journal of International Business Studies, vol. 46, no. 1, 2015, pp. 3-16, DOI:10.1057/jibs.2014.62.

[16] H. Chen, M.Z. Frank, O.Q. Wu. "U.S. Retail and Wholesale Inventory Performance from 1981 to 2004". Manufacturing \& Service Operations Management, Oct. 2007, Accessed: Jun. 07, 2020. [Online]

[17] F. Chouiraf, A. Chafi. "A new steps of Value Stream Mapping For the Moroccan Artisanal Enterprise." International Journal of Information Science \& Technology. Vol. 4, 2020.

[18] RM. del Rio. Chanona, P. Mealy, A. Pichler, F. Lafond and D. Farmer. "Supply and demand shocks in the COVID-19 pandemic: An industry and occupation perspective". arXiv:2004.06759 [econ, q-fin], Apr. 2020, Accessed: Jun. 07, 2020. [Online]. Available: http://arxiv.org/abs/2004.06759.

[19] K. Demeter, Z. Matyusz. "The impact of lean practices on inventory turnover". International Journal of Production Economics, vol. 133, no. 1, pp. 154-163, Sep. 2011. DOI:10.1016/j.ijpe.2009.10.031.

[20] E.W. Dickson, S. Singh, D.S. Cheung, C.C. Wyatt and A.S. Nugent. "Application of Lean Manufacturing Techniques in the Emergency Department". The Journal of Emergency Medicine, vol. 37, no. 2, 2009, pp. 177-182, DOI:10.1016/j.jemermed.2007.11.108.

[21] R. Djalante et al. "Review and analysis of current responses to COVID-19 in Indonesia: Period of January to March 2020". Progress in Disaster Science, vol. 6, 2020, p. 100091, DOI:10.1016/j.pdisas.2020.100091.

[22] J. Drew, B. McCallum, S. Roggenhofer and G. de Angéli. “Objectif lean: Réussir l'entreprise au plus juste: enjeux techniques et culturels". Broché, 2004.

[23] L. Driouach, K. Zarbane and Z. Beidouri. "Literature Review of Lean Manufacturing in Small and Medium-sized Enterprises". International Journal of Technology, vol. 10, no. 5, 2019, p. 930, DOI:10.14716/ijtech.v10i5.2718

[24] S. El Amine, A.N. Bouayad. "Distressed SMES in Morocco: Study on Common Characteristics". Journal of Research in Business and Management, vol. 8, 2020, pp. 36-44.

[25] A. Faure. " La comptabilité de la petite entreprise: de l'écriture au bilan". Chiron. 2009.

[26] R.R. Fullerton, C.S.S. McWatter, C. Fawson. "An examination of the relationships between JIT and financial performance". Journal of Operations Management, vol. 21 , no. 4, 2003, pp. 383-404, DOI:10.1016/S02726963(03)00002-0.

[27] G.D. Galsworth. Visual systems: Harnessing the power of the visual workplace. New York: American Management Association. 1997.

[28] A.M. Genaidy, W. Karwowski. "Human performance in lean production environment: Critical assessment and research framework". Human Factors and Ergonomics in Manufacturing and Service Industries, vol. 13, no 4, 2003, pp. 317-330.

[29] R.E. Goodson. "Read a plant-fast". Harvard Business Review, vol. 80, no. 5, 2002, pp. 105-1113.
[30] M. Greif. The Visual Factory: Building Participation Through Shared Information. CRC Press, 1991.

[31] R. Grewal, P. Tansuhaj. "Building Organizational Capabilities for Managing Economic Crisis: The Role of Market Orientation and Strategic Flexibility". Journal of Marketing, vol. 65, no. 2, 2001, pp. 67-80, DOI:10.1509/jmkg.65.2.67.18259.

[32] S. Gupta, S.K. Jain. "A literature review of lean manufacturing". International Journal of Management Science and Engineering Management, vol. 8, no. 4, 2013, pp. 241-249, DOI:10.1080/17509653.2013.825074.

[33] G. Hamel, C.K. Prahalad. Strategic Intent. Harvard Business Press, 2010.

[34] M. Hassainate. (2016). "Prévention de la défaillance des entreprises". Revue Marocaine de Recherche en Management et Marketing. [Online]. vol. 2(14). Available: https://revues.imist.ma/index.php?journal=REMAREM\&page=article\&op=view\&path\%5B\%5D=6413. [Jun. 07, 2020].

[35] Haut Commissariat au Plan. (2019). "Enquête Nationale Auprès Des Entreprises 2019, Premiers Résultats". Scribd. [Online]. Available: https://fr.scribd.com/document/449174324/Enquete-Nationale-Aupres-Des-Entreprises-2019-Premiers-Resultats-Version-Fr-1 [Jun. 11, 2020].

[36] Haut Commissariat au Plan. (2020). "Principaux résultats de l'enquête de conjoncture sur les effets du COVID-19 sur l'activité des entreprises", 2020. [Online]. Available: https://www.hcp.ma/Principaux-resultatsde-I-enquete-de-conjoncture-sur-les-effets-du-Covid19-sur-l-activite-des-entreprises_a2499.html.

[37] H. Hirano. 5S for operators: 5 Pillars of the visual workplace. NY: Productivity Press, 1996.

[38] Hofer, C., Eroglu, A. Rossiter. "The effect of lean production on financial performance: The mediating role of inventory leanness". International Journal of Production Economics, vol. 138, no. 2, 2012. pp. 242-253, DOI:10.1016/j.ijpe.2012.03.025.

[39] J.E. Humphries, C. Neilson, G. Ulyssea. "The Evolving Impacts of COVID-19 on Small Businesses Since the CARES Act". In Cowles Foundation for Research in Economics, paper No. 2230, 2020, Yale University, DOI:10.2139/ssrn.3584745

[40] M. Huson, D. Nanda. "The impact of just-in-time manufacturing on firm performance in the US". Journal of Operations Management, vol. 12, no. 3-4, 1995, pp. 297-310, DOI:10.1016/0272-6963(95)00011-G.

[41] Inforisk. (2017). "[Study] Défaillances D'entreprises Marocaines 2017 - Blog Inforisk,". http://blog.inforisk.ma/index.php/2018/03/30/etudedefaillances-dentreprises-marocaines-2017/ [Jun. 07, 2020].

[42] Inforisk. (2019). "[Study] Défaillances D'entreprises Au Maroc En 2019 - Blog Inforisk," http://blog.inforisk.ma/index.php/etudesdefaillances-2019/ [Jun. 07, 2020].

[43] Institut National d'analyse de la conjoncture and HCP. "Note de conjoncture", p. 47, 2020.

[44] Johnson. "Japanese-Style Management in America". California Management Review, vol. 30, no. 4, 1988, pp. 34-45, DOI:10.2307/41166525. 
[45] J. Kilpatrick. "Lean principles". Utah Manufacturing Extension Partnership, vol. 68, 2003, [Online].Available: http://yourcareeracademy.com/yca/assets/uploads/li b_file/Lean\%20Principles\%20-\%20overview.pdf. [Apr. 12, 2017].

[46] A. Kumar, M. Francisco. "Enterprise Size, Financing Patterns, and Credit Constraints in Brazil: Analysis of Data from the Investment Climate Assessment Survey". The World Bank, 2005.

[47] T. Laing. "The economic impact of the Coronavirus 2019 (COVID-2019): Implications for the mining industry". The Extractive Industries and Society, vol. 7, no 2, 2020, pp. 580-582, DOI:10.1016/j.exis.2020.04.003.

[48] Y. Larteb, A. Haddout, M. Benhadou. "Successful Lean Implementation: The Systematic and Simultaneous Consideration of Soft and Hard Lean Practices". International Journal of Engineering Research and General Science, vol. 3(2), 2015, pp. 1258-1270.

[49] N. Levratto, S. Barthelemy, M. Delhom, J.B. Filippi, and L. Maherault. (2002). "Conditions de l'élaboration d'une base de données qualitatives sur les entreprises aux fins d'une intermédiation informationnelle". [Online]. Available: http://www.bparanque.com/2irating/rapport2002v3.pdf [May 07, 2017].

[50] J.K. Liker. The Toyota way: 14 Management principles from the world's greatest manufacturer. New York: McGraw-Hill. 2004

[51] M. Liouaeddine. (2009). "La dynamique de la formation continue dans les P.M.E marocaines," University Library of Munich, Germany, 69815, [Online]. Available: https://ideas.repec.org/p/pra/mprapa/69815.html [Jun. 07, 2020].

[52] K.E. Mckone, R.G. Schroeder, K.O. Cua,. "The impact of total productive maintenance on manufacturing performance". Journal of Operations Management, vol. 19, no1, 2001, pp. 39-58.

[53] T. Melton. "The Benefits of Lean Manufacturing". Chemical Engineering Research and Design, vol. 83, no. 6, 2005, pp. 662-673, DOI:10.1205/cherd.04351.

[54] S. Mullarkey, P. Jackson, S. Parker. "Employee reactions to JIT manufacturing practices: A two-phase investigation". International Journal of Operations and Production Management, vol. 15, no 11, 1995, pp. 62-79.

[55] M. Nicola et al. "The socio-economic implications of the coronavirus pandemic (COVID-19): A review". International Journal of Surgery, vol. 78, 2020, pp. 185-193, DOI:10.1016/j.ijsu.2020.04.018.

[56] J.S. Oakland. "Total quality management: the route to improving performance" $2^{\text {nd }}$ ed. Oxford; Boston: Butterworth-Heinemann, 1995.

[57] G.C. Parry, C.E. Turner. "Application of lean visual process management tools". Production Planning \& Control, vol. 17, no. 1, 2006, pp. 77-86, DOI:10.1080/09537280500414991.

[58] D.A. Preece, R. Jones. "Introduction: Human Resource Development/Management in Lean Production". International Journal of Human Resources Development and Management, vol. 10, no. 1,2010 , p. 1 , DOI:10.1504/IJHRDM.2010.029676.
[59] L. Rivera, F. Frank Chen. "Measuring the impact of Lean tools on the cost-time investment of a product using cost-time profiles". Robotics and Computer-Integrated Manufacturing, vol. 23, no. 6, 2007, pp. 684-689, DOI:10.1016/j.rcim.2007.02.013.

[60] S. Sakakibara, B.B. Flynn, R.G. Schroeder, W.T Morris. "The Impact of Just-in-Time Manufacturing and Its Infrastructure on Manufacturing Performance". Management Science, vol. 43, no. 9, 1997, pp. 1246-1257, DOI:10.1287/mnsc.43.9.1246.

[61] R. Shah, P.T. Ward. "Defining and developing measures of lean production". Journal of Operations Management, vol. 25, no. 4, 2007, pp. 785-805, DOI:10.1016/j.jom.2007.01.019.

[62] A. Sharif, C. Aloui and L. Yarovaya. "COVID-19 pandemic, oil prices, stock market, geopolitical risk and policy uncertainty nexus in the US economy: Fresh evidence from the wavelet-based approach". International Review of Financial Analysis, vol. 70, 2020, p. 101496, DOI:10.1016/j.irfa.2020.101496.

[63] R. Shaw, Y. Kim and J. Hua. "Governance, technology and citizen behavior in pandemic: Lessons from COVID19 in East Asia". Progress in Disaster Science, vol. 6, 2020, p. 100090, DOI:10.1016/j.pdisas.2020.100090.

[64] W. Tani, B. Radi. (2014). "Le financement des Très Petites Entreprises: Informalisation du financement formel ou formalisation du financement informel", Available: $\quad$ http://www.redoreg.com/Tcomplet/TANI_3.pdf.

[65] D.J. Teece, G. Pisano, A. Shuen. "Dynamic capabilities and strategic management". Strategic Management Journal, vol. 18, no. 7, 1997, pp. 509-533, DOI:10.1002/(SICI)1097-0266(199708)18:7<509:AIDSMJ882>3.0.CO;2-Z.

[66] O. Torres. The Small and Medium-sized enterprise. Dominos Flammarion. 1999.

[67] S. Treville, J. Antonakis. "Could lean production job design be intrinsically motivating? Contextual, configurational, and levels-of-analysis issues". Journal of Operations Management, vol. 24, no. 2, 2006, pp. 99-123, DOI:10.1016/j.jom.2005.04.001.

[68] Tu, G.C. Hall. (2004). "Internationalization and Size, Age and Profitability in the United Kingdom". Social Science Research Network, Rochester, NY, SSRN Scholarly Paper ID 1497716. Accessed: [Online]. Available: https://papers.ssrn.com/abstract $=1497716$ [Jun. 07, 2020].

[69] UNDP, UNECA and World BANK. "Social \& Economic Impact Of The COVID 19 Crisis On Morocco, A Temporary Analysis To Assess The Potential For International Organizations To Support National Response," [Online]. Available: https://marokko.ahk.de/fileadmin/AHK_Marokko/Dokumente/Economic_and_Social_Impact_of_COVID_19_Morocco_UN_Impact_Assessment.pdf-2.pdf.pdf [Mar. 2020].

[70] A.M.E. Velda. "Impact of Supply Chain Management Practices on Financial Performance: Case Study of Automotive Suppliers in Morocco". 12 ${ }^{\text {th }}$ International Colloquium of Logistics and Supply Chain Management LOGISTIQUA, 12-14, IUT de Montreuil, Université Paris 8, France, 2019. 
[71] J.P. Womack, D.T. Jones, D. Roos. The Machine that Changed the World: The Story of Lean Production. 1990.

[72] S.M. Young. "A Framework for Successful Adoption and Performance of Japanese Manufacturing Practices in the United States". Academy of Management Review, vol. 17, no. 4, 1992, pp. 677-700, DOI:10.5465/amr.1992.4279060.

\section{Aicha Farissi}

ORCID ID: 0000-0001-7825-8149

High School of Technology Casablanca

Hassan II University of Casablanca

Mechanical \& Industrial Engineering

Laboratory Department

PO Box 8012, Oasis, Casablanca, Morocco

e-mail: aichafarissi11@gmail.com

\section{Laila Driouach}

ORCID ID: 0000-0002-4750-1393

High School of Technology Casablanca

Hassan II University of Casablanca

Mechanical \& Industrial Engineering

Laboratory Department

PO Box 8012, Oasis, Casablanca, Morocco

e-mail: laila.driouach@ensem.ac.ma

\section{Khalid Zarbane}

ORCID ID: 0000-0002-6048-5279

High School of Technology Casablanca

Hassan II University of Casablanca

Mechanical \& Industrial Engineering

Laboratory Department

PO Box 8012, Oasis, Casablanca, Morocco

e-mail: khalidzarbane@gmail.com

\section{Mohamed El Oumami}

ORCID ID: 0000-0003-3166-6529

High School of Technology Casablanca

Hassan II University of Casablanca

Mechanical \& Industrial Engineering

Laboratory Department

PO Box 8012, Oasis, Casablanca, Morocco

e-mail:mohoumami@gmail.com

\section{Zitouni Beidouri}

ORCID ID: 0000-0002-5347-7895

High School of Technology Casablanca

Hassan II University of Casablanca

Mechanical \& Industrial Engineering

Laboratory Department

PO Box 8012. Oasis. Casablanca. Morocco 